\title{
Eeniella, a New Yeast Genus of the Torulopsidales
}

\author{
MAUDY T. SMITH, ${ }^{1}$ WILMA H. BATENBURG-VAN DER VEGTE, ${ }^{2}$ AND W. A. SCHEFFERS ${ }^{2}$ \\ Yeast Division, Centraalbureau voor Schimmelcultures, ${ }^{1}$ and Laboratory of Microbiology, Delft University \\ of Technology, ${ }^{2} 2628$ BC Delft, The Netherlands
}

\begin{abstract}
We found that three yeast strains previously assigned to the genus Brettanomyces differed in reproduction and morphology from the known Brettanomyces species, and we transferred them to the new yeast genus Eeniella, with the single species Eeniella nana sp. nov. The type strain of E. nana is CBS 1945.
\end{abstract}

In the course of a revision of the genus Brettanomyces Kufferath et van Laer and its ascigerous state Dekkera van der Walt, we reexamined three strains in the Centraalbureau voor Schimmelcultures culture collection which are representatives of the invalidly described species Brettanomyces nanus (9). With a view toward validating the name, we performed a more detailed study of the morphology, physiology, and base composition of the deoxyribonucleic acids of these strains.

\section{MATERIALS AND METHODS}

Yeast strains. The strains used in this study were all isolated in 1952 by Gillis Een from bottled beer from different breweries in Sweden and included strain CBS 1945 from a brewery in Kalmar, strain CBS 1955 from a brewery in Stockholm, and strain CBS 1956 from a brewery in Göteborg. The reference strains used were the type strain (CBS 72) and strain CBS 3025 of the type species Brettanomyces bruxellensis Kufferath et van Laer, the type strain (CBS 6042) of Brettanomyces naardenensis Kolfschoten et Yarrow, and the type strain (CBS 479) of the type species Hanseniaspora valbyensis Klöcker.

Electron microscopy. After the cells were washed with water, they were fixed with $1.5 \%$ aqueous $\mathrm{KMnO}_{4}$ for $30 \mathrm{~min}$ at room temperature, washed again with water, and suspended in $2 \%$ agar. The cells were dehydrated in an ethanol series, stained with $1.5 \%$ uranyl acetate for $1.5 \mathrm{~h}$ at the $50 \%$ ethanol step, and finally embedded in Epon 812 or Spurr. Thin sections were cut with an LKB 4801A microtome, poststained with Reynolds lead citrate for $5 \mathrm{~min}$, and examined with a Philips model 201 transmission electron microscope at $60 \mathrm{kV}$.

Physiology. The physiological properties were investigated by the methods described by van der Walt (10). The strains used for the tests on the assimilation of carbon compounds were incubated on a shaker at 30 cycles per min for 28 days at $25^{\circ} \mathrm{C}$. We performed five assimilation tests per strain independently in parallel. The diazonium blue $B$ test was performed as described by van der Walt and Hopsu-Havu (12). Acetic acid production was detected by smell and was confirmed by gas chromatography.

Deoxyribonucleic acid base composition. Deoxyribonucleic acid was extracted from the cells by lysis with mercaptoethanol and sodium dodecyl sulfate and then purified by using the methods of Meyer and Phaff (6). Deoxyribonucleic acid base composition was determined by the thermal denaturation method, using the following formula (5): moles percent guanine plus cytosine $=($ thermal denaturation temperature 69.3)/0.41. Deoxyribonucleic acid from the type strain (CBS 604) of Candida parapsilosis (Ashf.) Langeron et Talice (thermal denaturation temperature, $85.9^{\circ} \mathrm{C}$ ) was included as the standard in all determinations.

\section{RESULTS}

Morphological characteristics. Light microscope examination revealed that after 3 days at $25^{\circ} \mathrm{C}$ in glucose yeast extract peptone water the cells were usually ogival to apiculate (1.8 to 4.5 by 2.2 to $7.5 \mu \mathrm{m}$ ), seldom spherical or cylindrical, and occurred singly or in pairs. Pearshaped (pyriform) cells also occurred (Fig. 1). After 1 month, a sediment was formed. Pseudohyphae were rarely observed in slide cultures on potato agar, rice agar, or cornmeal agar, and the cell form on agar was the same as the form in liquid medium. The shape of the cells indicated that conidiogenesis was bipolar, a characteristic observed in the Saccharomycodaceae, as well as in the genus Brettanomyces, which belongs to the order Torulopsidales. However, in the Saccharomycodaceae conidiogenesis is of the per current type (e.g., in $H$. valbyensis CBS 479 [19]) (Fig. 2), and in the Torulopsidales it is random in the apical zones, resulting in ogival to apiculate cells in young cultures of Brettanomyces strains and in rectangular (pillow-shaped [19]) cells in old Brettanomyces cultures (Fig. 3 ). These light microscope observations were complemented by electron microscope studies. In these studies, the reference strains $B$. bruxellensis CBS 72 and $B$. naardenensis CBS 6042 were included, as well as $H$. valbyensis CBS 479 (a representative of the Saccharomycodaceae). In strains CBS 1945, CBS 1955, and CBS 1956, multiple scar ridges were clearly confined to two opposite areas (Fig. 4 and 6). The bipolar conidiogenesis was of the percurrent type with progressive loci, as in $H$. valbyensis (3) (Fig. 5). We often observed a preference for budding on one 

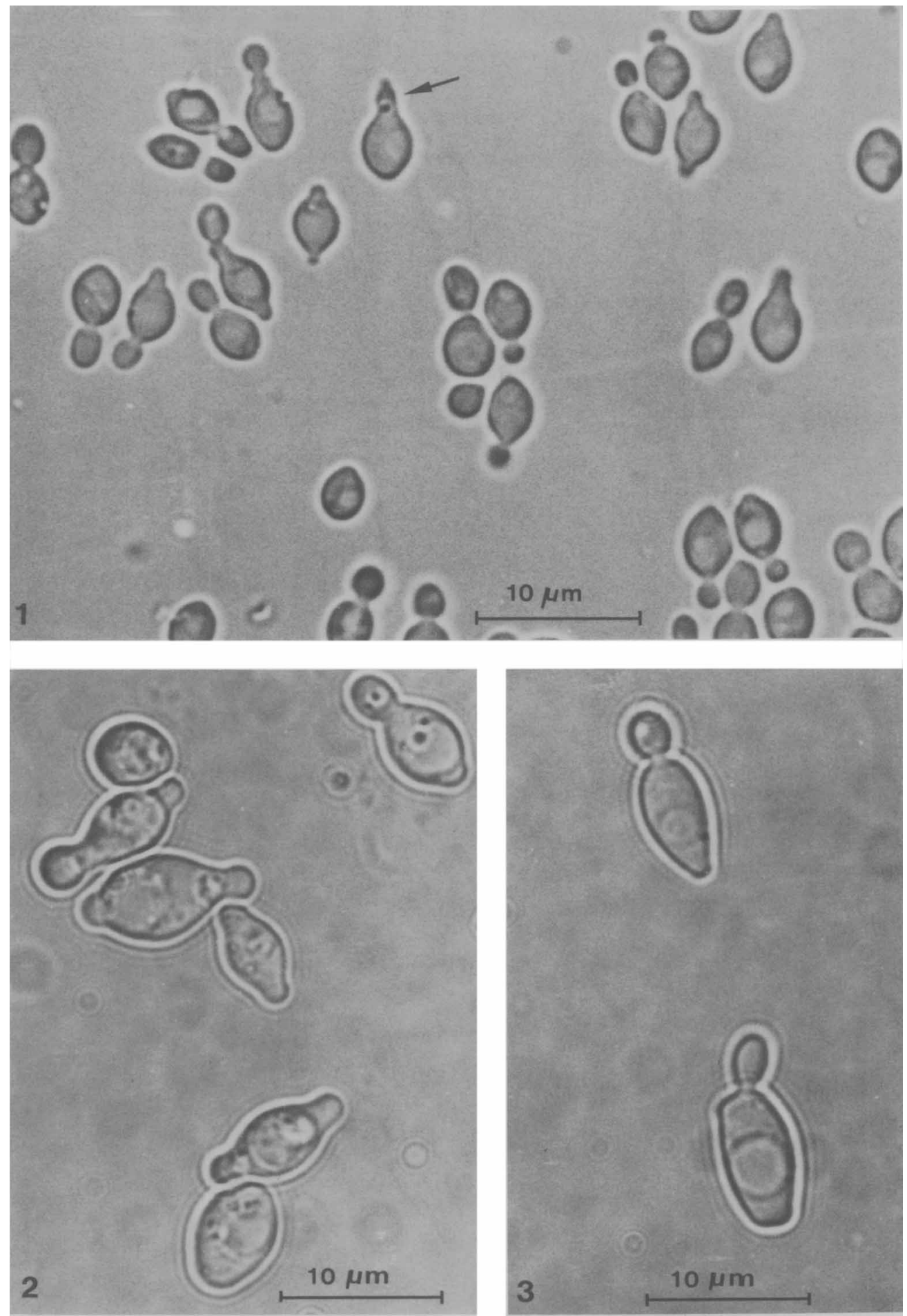

Fig. 1. E. nana CBS 1956 in $2 \%$ glucose- $0.5 \%$ yeast extract-1\% peptone water after 3 days at $25^{\circ} \mathrm{C}$. Bipolar, percurrent budding. Pyriform cells present (arrow).

Fig. 2. H. valbyensis CBS 479 in $2 \%$ glucose-0.5\% yeast extract-1\% peptone water after 3 days at $25^{\circ} \mathrm{C}$. Bipolar, percurrent budding.

FIg. 3. B. bruxellensis CBS 3025 in $2 \%$ glucose-0.5\% yeast extract-1\% peptone water after 3 days at $25^{\circ} \mathrm{C}$. One ogival and one rectangular cell. 
side, which caused extreme elongation of one end of the cell (Fig. 7). In B. bruxellensis (Fig. 8 ) and B. naardenensis (Fig. 9), buds and bud scars were observed side by side in the apical zones, indicating multilateral conidiogenesis.

Formation of ascospores. No ascospores were observed in individual cultures or in mixtures of cultures on normal sporulation media or media supplemented with vitamins (13).

Physiological characteristics. Fermentation tests were positive with $D$-glucose, and Dgalactose, negative with sucrose, maltose, lactose, raffinose, trehalose, melibiose, melezitose, inulin, soluble starch, and $\alpha$-methyl-D-glucoside, and variable between strains with cellobiose.

Assimilation tests were positive with D-glucose, D-galactose, cellobiose, L-rhamnose, ethanol, ribitol, D-mannitol, D-glucitol, salicin, and arbutin, negative with L-sorbose, sucrose, maltose, melibiose, raffinose, melezitose, inulin, soluble starch, L-arabinose, D-arabinose, D-ribose, glycerol, $i$-erythritol, galactitol, $\alpha$-methylD-glucoside, DL-lactic acid, succinic acid, citric acid, $i$-inositol, glucono- $\delta$-lactone, 2-ketogluconate, and D-glucosamine hydrochloride, and variable within strains with trehalose, lactose, and D-xylose.

Assimilation of $\mathrm{KNO}_{3}$ : negative.

Assimilation of ethylamine hydrochloride: positive.

Growth in vitamin-free medium: negative.

Growth on medium with $50 \%$ (wt/wt) glucose: negative.

Growth at $37^{\circ} \mathrm{C}$ : negative. Growth at $30^{\circ} \mathrm{C}$ : weakly positive. Growth at $3^{\circ} \mathrm{C}$ : positive.

Reaction with diazonium blue $\mathrm{B}$ : negative.

Additional properties included slow growth in malt extract and on malt agar, short-lived cultures, production of a characteristic aroma, production of acetic acid from glucose and ethanol under aerobic conditions, fermentation stimulated by molecular oxygen, and resistance to $1,000 \mu \mathrm{g}$ of cycloheximide (actidione) per $\mathrm{ml}$.

Deoxyribonucleic acid base composition. Table 1 shows the results of the thermal denaturation determinations and the calculated guanine-plus-cytosine values of the deoxyribonucleic acids.

\section{DISCUSSION}

Considering properties such as slow growth, brief life, production of a characteristic aroma, and, in particular, production of acetic acid from glucose under aerobic conditions, the strains examined fit the diagnosis of the genus Brettanomyces. Stimulation of fermentation of glucose by molecular oxygen was demonstrated by Scheffers (9) in these strains. This phenomenon is considered a characteristic feature of Brettanomyces species $(14 ;$ M. T. J. Custers, Ph.D. thesis, Delft University of Technology, Delft, The Netherlands, 1940), although it also has been observed in some other yeast genera (W. A. Scheffers and T. O. Wikén, Antonie van Leeuwenhoek J. Microbiol. Serol. 35[Suppl.]:A31A32, 1969). These strains are physiologically very similar to $B$. naardenensis Kolfschoten et Yarrow (1), from which they differ only in their inability to assimilate maltose, soluble starch, and succinic acid. However, in the manner of vegetative reproduction and, consequently, in the shape of the cells, there is an important difference from the species of Brettanomyces. From light microscopy as well as from electron microscopy, it is evident that the strains examined reproduce vegetatively by bipolar budding of the percurrent type, whereas Brettanomyces species reproduce vegetatively by multilateral budding localized in the apical zones. This difference in the manner of reproduction can be overlooked easily in young cultures, since in both types of reproduction, the young cells are ogival to apiculate after a few buddings. However, with the percurrent type of reproduction, the cells in old cultures keep their ogival to apiculate form, whereas the cells of Brettanomyces strains turn into rectangles (pillow-shaped [19]) by a somewhat restricted sympodial conidiogenesis at opposite sides. Since in generic differentiation the mode of vegetative reproduction and, consequently, cell morphology are more important than physiological properties (2, 7 ), the three strains examined cannot be considered members of the genus Brettanomyces; they must be recognized as representatives of a yeast genus with bipolar budding. The diazonium blue $B$ test and the morphology of the cell wall indicate the ascomycetous nature of these strains. Since they are asporogenous and fermentative, these strains might be assigned to the imperfect ascomycetous yeast genus Kloeckera Janke, the anamorph of the genus Hanseniaspora. However, in view of some properties, such as slow growth, brief life, production of a characteristic aroma, and, in particular, production of acetic acid from glucose under aerobic conditions (a feature to which importance is attached as a generic characteristic [11]), it seems appropriate to set the strains CBS 1945, CBS 1955, and CBS 1956 apart from the genus Kloeckera and to create a new genus to accommodate them.

This opinion is supported by the findings of Yamada et al. (18) concerning the coenzyme $Q$ 

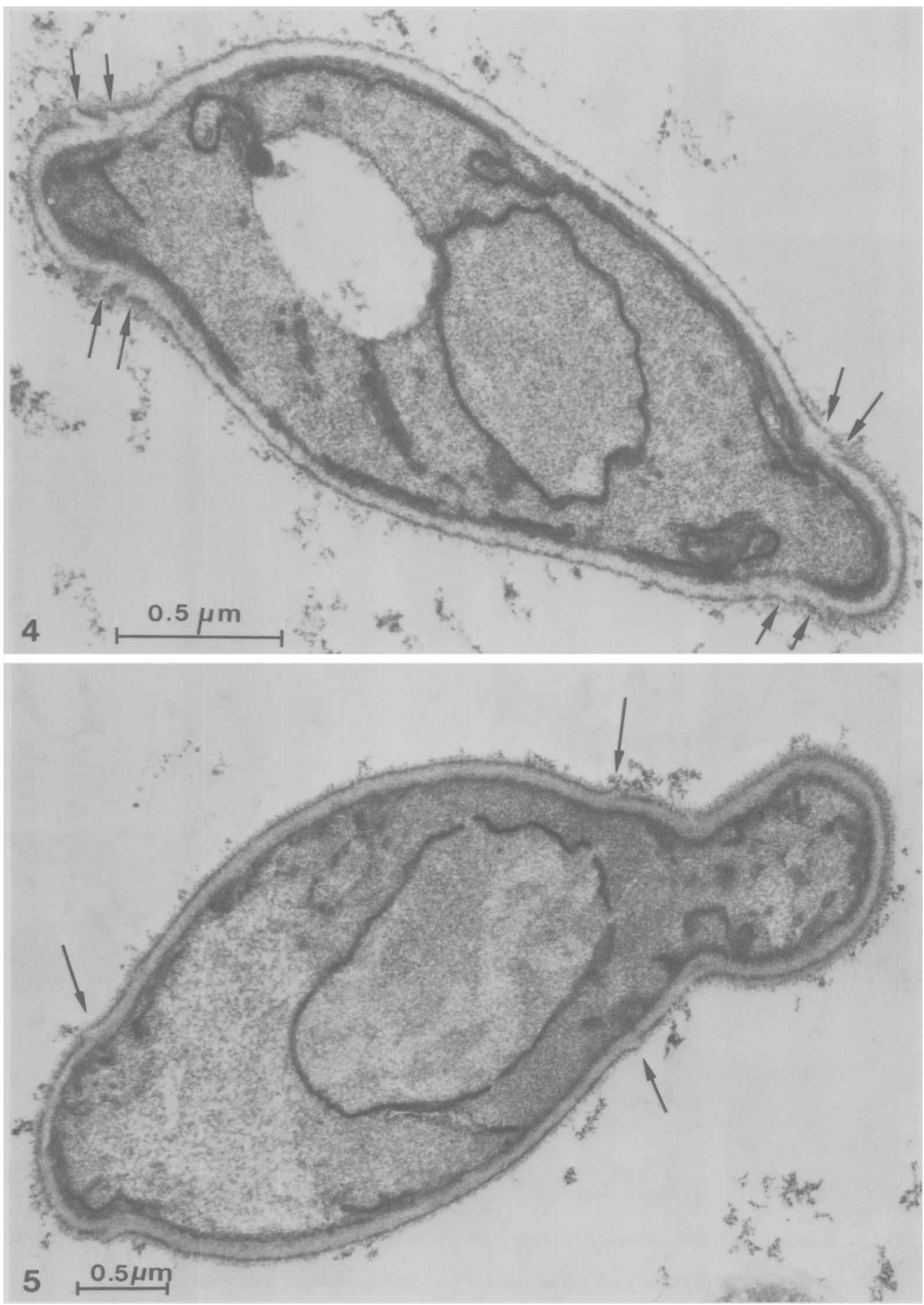

FIG. 4. E. nana CBS 1955. Two scar ridges are visible on both sides (arrows). FIG. 5. H. valbyensis CBS 479. Scar ridges present on both sides (arrows). 

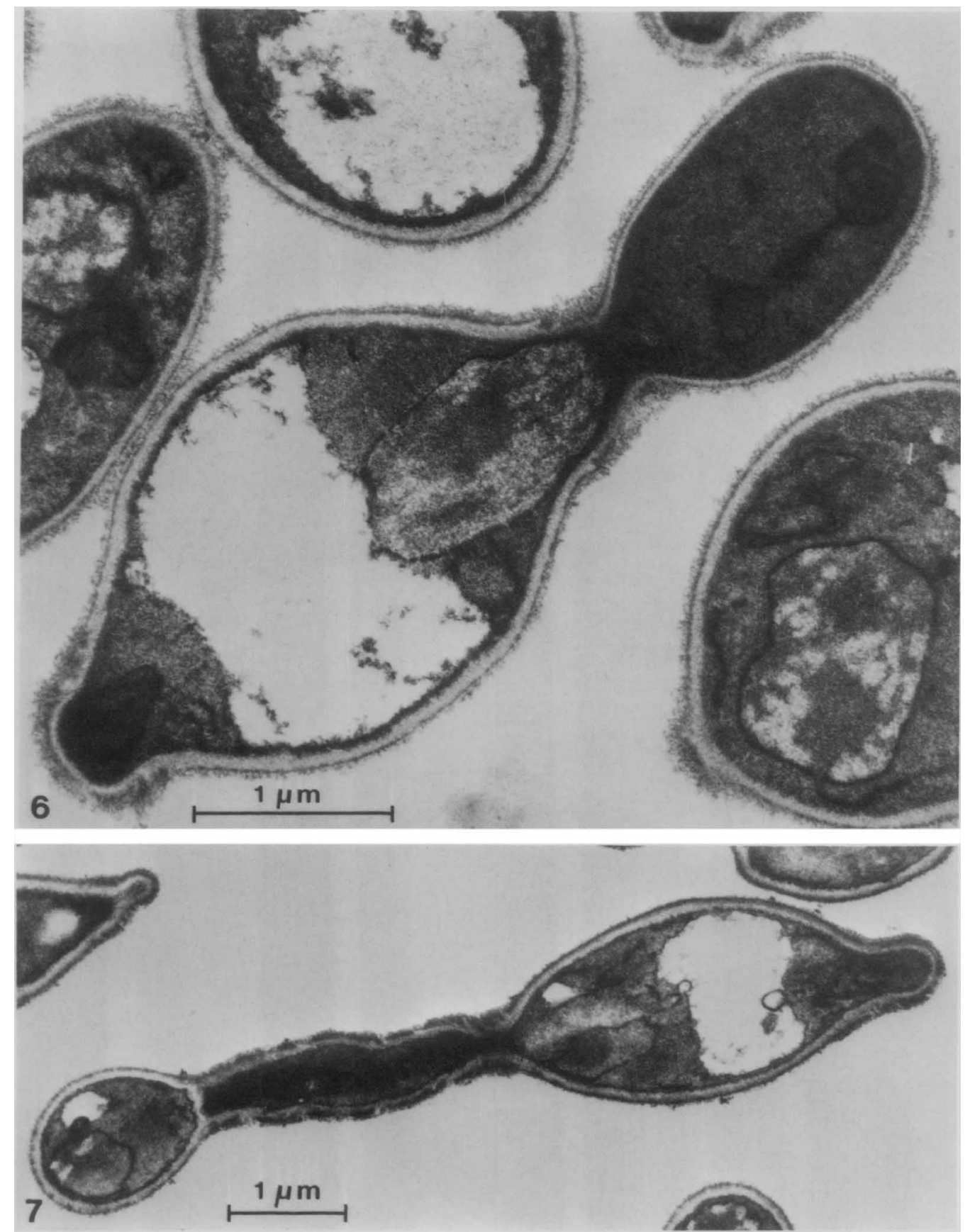

Fig. 6. E. nana CBS 1956. Several scar ridges on one side and one scar and one bud on the opposite side are visible.

Fig. 7. E. nana CBS 1945 cell with one elongated end having multiple scar ridges.

system in the genus Brettanomyces. All nine recognized species of Brettanomyces, as well as the invalid species $B$. nanus have the Q-9 system, whereas the species of the genus Kloeckera and its ascigerous state, Hanseniaspora, are characterized by the Q-6 ubiquinone system (15). Since the coenzyme $Q$ system is considered to be a valuable generic parameter $(4,8,16,17)$ 

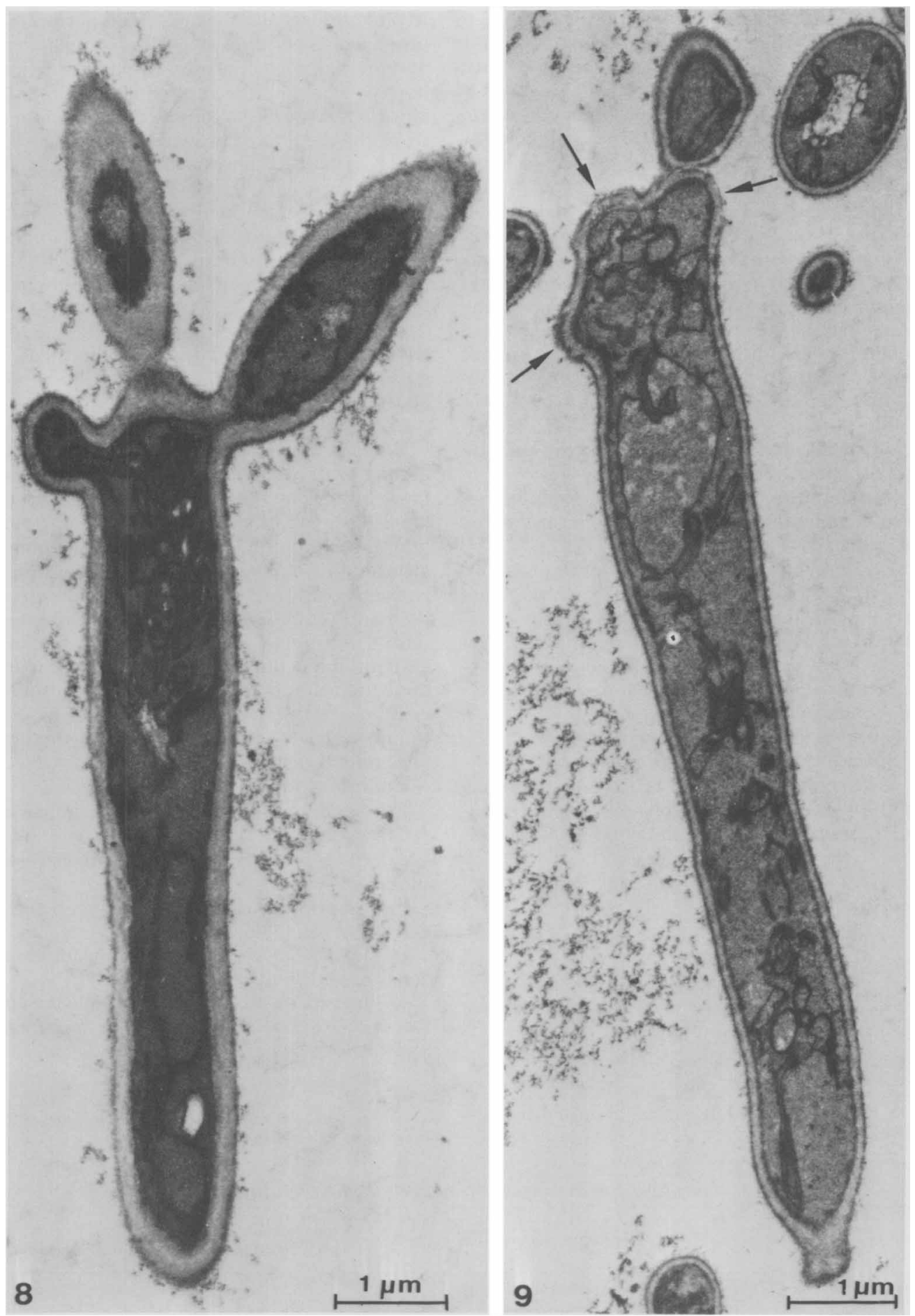

Fig. 8. B. bruxellensis CBS 72 cell showing three buds at one apical zone.

FIG. 9. B. naardenensis CBS 6042 cell showing three single bud scars at one apical zone (arrows). 
and in view of the above-mentioned characteristics, we feel justified in separating the three strains described above from the imperfect yeast genus Kloeckera and in creating a new genus.

For this genus we propose the name Eeniella gen. nov. in honor of Gillis Een, who isolated the strains, with the single species Eeniella nana sp. nov.

The epithet nana (Gr. for dwarf) was chosen because of the small size of the cells.

Since the genus Eeniella resembles the genus Kloeckera in its morphology and the genus Bret. tanomyces in its physiology, elucidation of the possible phylogenetic relationships among these genera will require further study. The salient generic characteristics of Brettanomyces, Eeniella, and Kloeckera are summarized in Table 2.

Latin diagnosis and description of the taxa. (i) Eeniella gen. nov.

Gemmatio bipolaris percurrens. Cellulae obtuso-acuminatae vel apiculatae, raro rotundatae ad cylindricae.

Pseudohyphae parcae. Ascosporae absentes. In extracto malti et agaro malti culturae lente crescunt et ad mortem praematuram propensae. Odor insignitus aromaticus. In conditione aerobia acidum aceticum e glucoso plerumque vehementur. Fermentatio glucosi plerumque oxygeno moleculari augetur.

Systema ubiquinoni typi Q-9.

Species typica: Eeniella nana sp. nov.

Vegetative reproduction is by bipolar budding of the percurrent type. Cells are ogival to apiculate, seldom spherical to cylindrical. Pseudo-

TABLE 1. DNA base compositions of E. nana strains

\begin{tabular}{ccc}
\hline Strain & $\begin{array}{c}\text { Thermal denatura- } \\
\text { tion temp }\left({ }^{\circ} \mathrm{C}\right)\end{array}$ & $\begin{array}{c}\text { Guanine-plus-cyto- } \\
\text { sine content }(\mathrm{mol} \%)\end{array}$ \\
\hline CBS 1945 & $86.10 \pm 0.19^{a}$ & $41.0 \pm 0.5^{a}$ \\
CBS 1955 & $86.26 \pm 0.19$ & $41.4 \pm 0.5$ \\
CBS 1956 & $85.80 \pm 0.15$ & $40.2 \pm 0.4$ \\
\hline
\end{tabular}

${ }^{a}$ Mean \pm standard deviation (average of five determinations). hyphae are seldom formed. Ascospores are not produced. Slow growth occurs in malt extract and on malt agar. Cultures are generally shortlived. A characteristic aroma is produced. Usually there is vigorous production of acetic acid from glucose under aerobic conditions. Fermentation is present and usually is stimulated by molecular oxygen. The Q-9 ubiquinone is present in the electron transport system. The type species of the genus is Eeniella nana sp. nov.

(ii) Eeniella nana sp. nov. Synonym: Brettanomyces nanus nom. inval. Art. 36 (Scheffers 1966).

Cellulae ovoidae vel apiculatae $(1.8-4.5 \times 2.2-$ $7.5 \mu \mathrm{m})$, rarius rotundatae vel cylindricae, singulae vel binae. Cultura butyrosa, glabra, nitida, eburnea.

Pseudohyphae parcae. Ascosporae nullae.

Glucosum et galactosum fermentantur. Glucosum, galactosum, cellobiosum, trehalosum (variabiliter), lactosum (variabiliter), D-xylosum (variabiliter), L-rhamnosum, ethanolum, ribitolum, D-mannitolum, D-glucitolum, salicinum, et arbutinum assimilantur, neque $\mathrm{L}$-sorbosum, saccharum, maltosum, melibiosum, raffinosum, melezitosum, inulinum, amylum solubile, L-arabinosum, D-arabinosum, D-ribosum, glycerolum, $i$ erythritolum, dulcitolum, $\alpha$-methyl-D-glucosidum, DL-acidum lacticum, acidum succinicum, acidum citricum, $i$-inositolum, glucono- $\delta$-lactonum, calcii-2-keto-gluconatum, et D-glucosaminum hydrochloricum.

Kalii nitratum non assimilatur.

Ethylaminum hydrochloricum assimilatur.

Crescere non potest $37^{\circ} \mathrm{C}$.

Ad crescentiam vitamina externa necessaria sunt.

In conditione aerobia acidum aceticum exglucoso et ethanolo formatur.

Proportio molaris guanini + cytosini in acido deoxyribonucleinico: $40.2-41.4 \mathrm{~mol} \%$.

Typus isolatus ex cerevisiae in Suecia depositus in collectione Centraalbureau voor Schimmelcultures, Delphi (CBS 1945).

\section{ACKNOWLEDGMENTS}

We are indebted to D. Yarrow, W. Gams, and G. S. de Hoog for valuable discussions.

TABLE 2. Salient generic characteristics of Brettanomyces, Eeniella, and Kloeckera

\begin{tabular}{|c|c|c|c|c|}
\hline Genus & Vegetative reproduction & $\begin{array}{l}\text { Production of } \\
\text { acetic acid }\end{array}$ & $\begin{array}{c}\text { Fermentation } \\
\text { stimulated by } \\
\text { molecular } \mathrm{O}_{2}\end{array}$ & $\begin{array}{c}\text { Coenzyme } Q \\
\text { system }\end{array}$ \\
\hline Brettanomyces & $\begin{array}{l}\text { Multilateral budding in } \\
\text { apical zones }\end{array}$ & + & + & 9 \\
\hline Eeniella & Percurrent budding, bipolar & + & + & 9 \\
\hline Kloeckera & Percurrent budding, bipolar & - & - & 6 \\
\hline
\end{tabular}




\section{REPRINT REQUESTS}

Address reprint requests to: $M$. Th. Smith, Yeast Division, Centraalbureau voor Schimmelcultures, Laboratory of Microbiology, Delft University of Technology, Julianalaan 67a, 2628 BC Delft, The Netherlands.

\section{LITERATURE CITED}

1. Kolfschoten, G. A., and D. Yarrow. 1970. Brettanomyces naardenensis, a new yeast from soft drinks. Antonie van Leeuwenhoek J. Microbiol. Serol. 36:458460.

2. Kreger-van Rij, N. J. W. 1969. Taxonomy and systematics of yeasts, p. 5-78. In A. H. Rose and J. S. Harrison (ed.), The yeasts, vol. 1. Academic Press, Inc., London.

3. Kreger-van Rij, N. J. W., and M. Veenhuis. 1971. Bipolar budding in yeasts-an electron microscope study. Antonie van Leeuwenhoek J. Microbiol. Serol. 37:125-136.

4. Kurtzman, C. P., M. J. Smiley, and C. J. Johnson. 1980. Emendation of the genus Issatchenkia Kudriavzev and comparison of species by deoxyribonucleic acid reassociation, mating reaction, and ascospore ultrastructure. Int. J. Syst. Bacteriol. 30:503-513.

5. Marmur, J., and P. Doty. 1962. Determination of the base composition of deoxyribonucleic acid from its thermal denaturation temperature. J. Mol. Biol. 5:109-118.

6. Meyer, S. A., and H. J. Phaff. 1969. Deoxyribonucleic acid base composition in yeasts. J. Bacteriol. 97:52-56.

7. Phaff, H. J., M. W. Miller, and E. M. Mrak. 1978. The life of yeasts, 2nd ed. Harvard University Press, Cambridge, Mass.

8. Price, C. W., G. B. Fuson, and H. J. Phaff. 1978 Genome comparison in yeast systematics: delimitation of species within the genera Schwanniomyces, Saccharomyces, Debaryomyces, and Pichia. Microbiol. Rev. 42:161-193.

9. Scheffers, W. A. 1966. Stimulation of fermentation in yeasts by acetoin and oxygen. Nature (London) 210: 533-534.

10. van der Walt, J. P. 1970. Criteria and methods used in classification, p. 34-113. In J. Lodder (ed.), The yeasts.
A taxonomic study. North-Holland Publishing Co., Amsterdam.

11. van der Walt, J. P. 1970. Brettanomyces Kufferath et van Laer, p. 863-892. In J. Lodder (ed.), The yeasts. A taxonomic study. North-Holland Publishing Co., Amsterdam.

12. van der Walt, J. P., and V. K. Hopsu-Havu. 1976. A colour reaction for the differentiation of ascomycetous and hemibasidiomycetous yeasts. Antonie van Leeuwenhoek J. Microbiol. Serol. 42:157-163.

13. van der Walt, J. P., and A. E. van Kerken. 1960. The wine yeasts of the Cape. IV. Ascospore formation in the genus Brettanomyces. Antonie van Leeuwenhoek J. Microbiol. Serol. 26:292-296.

14. Wikén, T., W. A. Scheffers, and A. J. M. Verhaar. 1961. On the existence of a negative Pasteur effect in yeasts classified in the genus Brettanomyces Kufferath et van Laer. Antonie van Leeuwenhoek J. Microbiol. Serol. 27:401-433.

15. Yamada, Y., M. Arimoto, and K. Kondo. 1976. Coenzyme Q system in the classification of apiculate yeasts in the genera Nadsonia, Saccharomycodes, Hansen. iaspora, Kloeckera, and Wickerhamia. J. Gen. Appl. Microbiol. 22:293-299.

16. Yamada, Y., M. Arimoto, and K. Kondo. 1977. Coenzyme Q system in the classification of some ascosporogenous yeast genera in the families Saccharomycetaceae and Spermophthoraceae. Antonie van Leeuwenhoek J. Microbiol. Serol. 43:65-71.

17. Yamada, Y., M. Nojiri, M. Matsuyama, and K. Kondo. 1976. Coenzyme Q system in the classification of the ascosporogenous yeast genera Debaryomyces, Saccharomyces, Kluyveromyces, and Endomycopsis. J. Gen. Appl. Microbiol. 22:325-337.

18. Yamada, Y., H. Takinami-Nakamura, Y. Tahara, and M.T. Smith. 1980. The coenzyme $Q$ system in the classification of the ascosporogenous yeast genus Dek. ker $a$ and the asporogenous yeast genus Brettanomyces. Antonie van Leeuwenhoek J. Microbiol. Serol. 46:595599.

19. Zsolt, J., and E. K. Novák. 1977. Some remarks on the vegetative reproduction of yeasts, p. 39-40. In E. K. Novák, T. Deák, T. Török, and J. Zsolt (ed.), Proceedings of the Fifth International Specialized Symposium on Yeasts, Part I. Keszthely, Budapest. 